\title{
PENGARUH PERSEPSI MASYARAKAT PADA KINERJA KEPOLISIAN TERHADAP KEPERCAYAAN PADA KEPOLISIAN
}

\author{
Lina Febrianti* \\ Herdiyan Maulana** \\ *Fakultas Ilmu Pendidikan, Universitas Negeri Jakarta \\ **Fakultas Ilmu Pendidikan, Universitas Negeri Jakarta
}

DOI: https://doi.org/10.21009/JPPP.021.09

\section{Alamat Korespondensi:}

lina_psiunj08@yahoo.com

\begin{abstract}
This study aims to look at the effect on the public perception of trust in the police. The research was conducted in December 2012. The design of this this study is a quantitative method. Subjects in this research were 124 citizen in the Jabodetabek area with an age range of 18 years and minimum of High School education/equivalent. It's using the incidental technique sampling to get the sample. Data of this research was collected by the instrument which has 27 aitem perception and trust instrument which has 37 items. These results show that there is a significant effect between perceptions of trust in the police. Perceptions positive effect on confidence. So Ho is rejected and Ha accepted perceptions of the effective contribution of $37.5 \%$ confidence.
\end{abstract}

Keywords

public perception, police performance, trust, police

\section{Pendahuluan}

Kepolisian Negara Republik Indonesia merupakan instrumen negara yang berperan dalam memelihara keamanan dan ketertiban masyarakat, menegakkan hukum serta memberikan perlindungan, pengayoman, dan pelayanan kepada masyarakat dalam rangka terpeliharanya keamanan dalam negeri sesuai dengan Pasal 5 UU No.2 Tahun 2002. Kepolisian, memiliki kewenangan dalam menyelesaikan permasalah yang terjadi baik masalah pidana maupun masalah perdata. Tujuan dibentuknya kepolisian menurut undang-undang dasar negara 1945 Pasal 4 UU No.2 Tahun 2002 adalah untuk mewujudkan keamanan dalam negeri yang meliputi terpeliharanya keamanan dan ketertiban masyarakat, tertib dan tegaknya hukum, terselenggaranya perlindungan, pengayoman dan pelayanan masyarakat, serta terbinanya ketentraman masyarakat dengan menjunjung tinggi hak asasi manusia.

Terkait dengan tugas dan tanggungjawab yang diemban oleh institusi kepolisian, kinerja kepolisian merupakan bagian yang mendapat perhatian dari masyarakat. Beberapa waktu belakangan kepolisian mendapat sorotan publik terkait dengan kasus cicak-buaya. Isu mengenai kinerja kepolisian tidak hanya pada kasus cicak vs buaya, sepanjang tahun 2009-2010, akuntabilitas kepolisian di mata publik juga semakin menurun. Indikator yang muncul tidak lain berasal dari internal kepolisian sendiri, di antaranya dugaan terjadinya tindak kekerasan dan penyalahgunaan kekuasaan (http://www.kontras.org/index). Hal yang paling menonjol pada pertengahan tahun 2010 adalah dugaan korupsi atau dikenal dengan rekening gendut sebagaimana pernah diterbitkan majalah Tempo edisi 4 Juli 2010. Padahal sebagai organisasi penegak hukum, kepolisian tentu 
diharapkan akan mampu menangani dan menyelesaikan kasus-kasus besar yang terjadi. Kasus korupsi yang membelit kepolisian tentu juga akan memperburuk kredibilitas kepolisian.

Sehubungan dengan berbagai isu mengenai kinerja kepolisian serta hal-hal yang berhubungan dengan kewenangannya pada tanggal 17 Juni hingga 4 Juli 2011 The Indonesian Human Rights Monitor melakukan survey pada warga DKI Jakarta. Hasil survey yang dilakukan pada 500 warga DKI Jakarta mengenai kinerja kepolisian menunjukkan hasil bahwa sebesar 61 persen masyarakat tidak puas dan sisanya sebanyak 33 persen merasa puas. Hasil survei menunjukkan, penanganan korupsi menduduki tingkat ketidakpuasan paling tinggi sebesar 78,4 persen. Sementara penanganan terorisme memiliki tingkat kepuasan tertinggi dengan 67 persen. 25,2 persen mengaku tidak puas dan 7,8 persen menjawab tidak tahu atas prestasi itu. Sebesar 59,20 persen menyatakan polisi terlibat dalam perdagangan narkotika. Sedangkan penyimpangan berupa penyiksaan yang dilakukan kepolisian saat penangkapan atau dinilai masyarakat sebanyak 49,40 persen. Survei ini meneliti kinerja polisi pada pelbagai bidang seperti penanganan korupsi, lalu lintas, curanmor, Narkotika, kasus SARA, terorisme dan lain-lain.

Berdasarkan pemaparan di atas jelas terlihat bahwa berbagai permasalahan yang berkaitan dengan kinerja sedang dihadapi oleh pihak kepolisian. Ada prestasi yang berhasil diraih, namun permasalahan yang mencoreng institusi ini juga tidak kalah ramainya mewarnai pemberitaan. Ketika dalam masalah penanganan terorisme dan narkotika kepolisian masih mendapat apresiasi namun permasalahan korupsi yang melibatkan aparat kepolisian membuat citra kepolisian tidak populer lagi.

Terkait dengan penilaian terhadap kinerja kepolisian sebagai organisasi publik tentu aspek masyarakat memiliki peranan besar. Masyarakat sebagai bagian dari stakeholders organisasi ini memiliki andil dalam memberikan penilaian terhadap kinerja yang telah dilakukan oleh kepolisian. Penilaian kinerja kepolisian oleh masyarakat tentu dimaksudkan sebagai upaya mengedepankan aspek objektivitas.

Tuntutan tugas dan tanggung jawab kepolisian yang sedemikian besarnya tentu sangat memerlukan dukungan dan kerjasama tim yang solid. Kepolisian sebagai organisasi publik juga memerlukan dukungan serta kerjasama dari masyarakat. Dukungan dan kerja sama masyarakat dalam menunjang tugas kepolisian bisa terlihat dalam bentuk kepercayaan yang diberikan. Kepercayaan masyarakat tentu harus didukung pula oleh kesungguhan kepolisian dalam menangani berbagai kasus tersebut. Kepercayaan masyarakat terhadap kepolisian merupakan hal yang sangat penting. Kepercayaan merupakan komponen dasar untuk membentuk hubungan yang kooperatif (Blau 1964, Deutsch 1973, Pruitt 1981, dalam Hutapea 2008). Gabriel Almond dan Sydney Verba dalam The Civic Culture (1963) dan Robert D Putnam dalam Making Democracy Work (1993) mengatakan, bahwa trust merupakan elemen vital yang menghasilkan dukungan politik yang memungkinkan lembaga-lembaga demokratik survive dan melaksanakan fungsinya secara efektif (http://bataviase.co.id/node/286595).

Kepercayaan dipengaruhi oleh pengalaman masa lalu mengenai hal yang bersangkutan. Menurut Forsyth 1990, pengalaman positif yang konsisten dimasa lalu dengan satu pihak akan meningkatkan rasa percaya sehingga akan menumbuhkan harapan akan hubungan yang baik di masa yang akan datang (Hutapea, 2008). Kepercayaan harus dibangun oleh semua pihak pada setiap organisasi kehidupan, mulai dari organisasi keluarga, organisasi pendidikan, organisasi masyarakat, dan organisasi pemerintah (Ancok, 2007). Kepercayan terdiri atas banyak faktor yaitu kognitif, emosional dan tingkah laku, yang semuanya merupakan efek dari persepsi individu terhadap kepercayaan (Paine, 2003).

Kepercayaan terhadap suatu organisasi, kelompok, maupun individu berawal pada bagaimana orang mempersepsikan hal tersebut. Sikap percaya individu akan dipengaruhi oleh persepsi individu pada maksud individu lain dalam hubungannya dengan maksud individu tersebut (Rakhmat, 2007).

Polisi sebagai Organisasi publik tentu juga mendapat pengamatan dari masyarakat sehingga bisa menimbulkan suatu persepsi dalam masyarakat. Persepsi sering diartikan sebagai proses mempersepsi objek-objek dan peristiwa untuk mencoba memahami apa yang tampak dan 
tidak tampak pada alat inderanya. Menurut Baron \& Byrne (2005) bahwa terdapat dua aspek utama dalam usaha untuk memahami orang orang lain. Pertama, kita selalu berusaha untuk memahami perasaan, mood dan emosi orang lain - bagaimana perasaan mereka pada tempat dan waktu tertentu, informasi tersebut sering diperoleh melalui pengamatan pada aspek-aspek non verbal individu lain. Kedua, kita kemudian berusaha untuk memahami penyebab mendasar yang mempunyai efek lebih lama bagi perilaku seseorang seperti trait, motif dan intensi.

Persepsi masyarakat terhadap kepolisian juga bisa dipengaruhi oleh kinerja kepolisian. Masyarakat sebagai penerima jasa layanan yang diberikan oleh pihak kepolisian tentu memiliki penilaian sendiri terhadap kinerja yang telah dilakukan kepolisian terkait dengan tugasnya.

Berdasarkan pemaparan di atas maka dapat terlihat bahwa dalam beberapa kasus kepolisian mendapat penilaian positif dari masyarakat sedangkan dalam kasus lain masyarakat menilai negatif. Berdasarkan hal-hal yang telah di jelaskan di atas maka peneliti tertarik untuk mengetahui bagaimana pengaruh persepsi masyarakat pada kinerja kepolisian terhadap kepercayaan pada kepolisian.

\section{Kepercayaan (trust)}

Kepercayaan (trust) merupakan komponen yang penting dalam menjalani suatu hubungan interpersonal. Secara ilmiah kepercayaan didefinisikan sebagai mengandalkan perilaku individu lain untuk mencapai tujuan yang dikehendaki, yang pencapaiannya tidak pasti dan dalam situasi yang penuh risiko (Giffin, dalam Rakhmat 2007). Menurut Nelken (1994) kepercayaan ada dua macam, pertama kepercayaan antar pribadi dan kedua kepercayaan dalam sistem yang impersonal (Suparlan, 2004). Kepercayaan adalah pengharapan yang muncul dalam sebuah komunitas yang berperilaku normal, jujur dan kooperatif, berdasarkan norma-norma yang dimiliki bersama, demi kepentingan anggota yang lain dari komunitas itu (Fukuyama, 2002). Kepercayaan adalah harapan yang dimiliki oleh seseorang atau kelompok pada kata-kata, janji, dan bahwa verbal maupun tertulis dari individu lain atau kelompok lain yang dapat diandalkan (Rotter, 1967 dalam Yamagishi 1998). Mayer
(1995) mendefinisikan kepercayaan sebagai kesediaan salah satu pihak menerima tindakan pihak lain yang didasarkan pada harapan bahwa pihak lain akan melakukan tindakan yang penting untuknya, terlepas dari kemampuan untuk memonitor atau mengendalikan pihak lain (Macaskill, 2009).

Proses seseorang mempercayai orang lain tentu dibentuk oleh unsur-unsur dari dimensi kepercayaan. Robbins (2003) dalam bukunya menjelaskan lima dimensi kunci yang melandasi kepercayaan. Dimensi kunci yang melandasi konsep tentang kepercayaan adalah keterpaduan yang merujuk pada kejujuran dan keadaan yang sebenarnya, kompetensi, konsistensi, loyalitas yaitu keinginan untuk memproteksi dan menyelamatkan wajah dari orang lain, dan keterbukaan. Jim Grunig telah mengidentifikasi tiga dimensi kepercayaan yaitu: kompetensi, integritas, reliabilitas. Pamela S. ShockleyZalabak, dkk (2010) menjelaskan bahwa ada lima dimensi kunci dari kepercayaan yaitu: kemampuan, keterbukaan, perhatian, reliabilitas, dan identifikasi.

Jadi berdasarkan definisi yang dijelaskan di atas, maka definisi kepercayaan yang digunakan dalam penelitian ini adalah kesedian masyarakat untuk menerima kepolisian berdasarkan harapan positif bahwa kepolisian memiliki kemampuan, terbuka, memiliki perhatian, dapat diandalkan dan mencerminkan institusinya.

\section{Persepsi}

Persepsi melibatkan cara kita memandang dunia sekitar kita, menambahkan makna pada informasi yang dikumpulkan melalui lima indera yaitu sentuhan, penciuman, penglihatan pendengaran, dan rasa. Persepsi adalah sarana utama untuk mengetahui melalui mana individu mengerti dirinya sendiri dan sekitarnya (Nelson, 2005). Menurut Irwanto (2002), persepsi adalah suatu proses penerimaan rangsangan yang menimbulkan suatu pengertian terhadap lingkungan. Menurut Pareek (dalam Sobur, 2003), persepsi dapat didefinisikan sebagai proses menerima, menyeleksi, mengorganisasikan, menguji dan memberikan reaksi kepada rangsangan pancaindra atau data. Menurut Gibson dkk (2003) persepsi adalah proses di mana individu memberikan makna pada lingkungan. 
Santrock (2003), mendefinisikan persepsi sebagai proses otak dalam mengorganisasi dan menginterpretasikan informasi dari sensori untuk mendapatkan makna. Jadi persepsi dapat dikatakan sebagai suatu proses penerimaan stimulus dari luar kemudian diberi makna sehingga menghasilkan sikap dan perilaku terhadap stimulus yang diterima tersebut.

\section{Kinerja}

Kinerja dapat didefinisikan sebagai kuantitas dan kualitas individu, kelompok, atau prestasi suatu organisasi. Kinerja adalah hasil dari pengukuran atas kuantitas dan kualitas serta kontribusi pada tugas yang dilakukan oleh individu atau kelompok untuk unit kerja dan organisasinya (Wood, 1998).

Menurut Rivai (2003) kinerja merupakan suatu fungsi dari motivasi dan kemampuan untuk menyelesaikan tugas atau pekerjaan seseorang sepatutnya memiliki derajat kesediaan dan tingkat kemampuan tertentu.

Menurut Mangkunegara (2000) kinerja karyawan adalah hasil kerja secara kualitas dan kuantitas yang dicapai oleh seorang karyawan dalam melaksanakan tugasnya sesuai dengan tanggung jawab yang diberikan kepadanya.

Lebih lanjut menurut Suyadi Prawirosentono (2008), kinerja adalah hasil kerja yang dapat dicapai oleh seseorang atau sekelompok orang dalam satu organisasi, sesuai dengan wewenang dan tanggung jawab masing-masing, dalam rangka mencapai tujuan organisasi yang bersangkutan secara legal, tidak melanggar hukum dan sesuai dengan moral dan etika.

\section{Persepsi Kinerja}

Persepsi dapat dikatakan sebagai suatu proses penerimaan stimulus dari luar kemudian diberi makna sehingga menghasilkan sikap dan perilaku terhadap stimulus yang diterima tersebut. Hal ini berarti bahwa proses pemaknaan yang terjadi saat seseorang menerima rangsangan akan memberikan pengaruh terhadap tingkah lakunya pada hal yang dipersepsikannya itu.

Kinerja merupakan hasil kerja seseorang atau sekolompok orang untuk melakukan suatu kegiatan dalam menjalankan kewajibannya sesuai dengan tanggung jawabnya untuk mencapai hasil yang diharapkan sesuai dengan tujuan organisasi tanpa melakukan pelanggaran hukum. Terkait dengan kinerja, kepolisian sebagai organisasi publik berorientasi pada kualitas layanan yang diberikan pada masyarakat. Stephen D. Mastrofski (Maguire, 2010) merumuskan enam dimensi yang dapat digunakan dalam mengukur kinerja kepolisian terkait dengan kualitas layanan yaitu, perhatian, reliabiliti, responsibiliti, kemampuan, sikap, dan kejujuran.

Berdasarkan penjelasan di atas maka definisi persepsi pada kinerja yang digunakan dalam penelitian ini adalah proses penerimaan informasi oleh masyarakat mengenai unjuk kerja yang dilakukan oleh kepolisian dalam menjalankan tugas yang diukur melalui lima aspek kinerja kepolisian yang diungkapkan oleh Stephen D. Mastrofski yaitu, perhatian, keandalan (reliabiliti), responsibiliti, kemampuan, sikap dan kejujuran.

\section{Metode Penelitian}

Tipe penelitian yang digunakan dalam penelitian ini adalah penelitian kuantitatif. Populasi dalam penelitian ini adalah masyarakat Jabodetabek. Subjek penelitian ini memiliki karakteristik sebagai berikut, berdomisili di Jabodetabek, usia 18 tahun ke atas, pendidikan SMA ke atas. Teknik sampling yang dilakukan dalam penelitian ini adalah non probabilitas sampling. Teknik non probalitas yang digunakan adalah jenis accidental sampling. Jumlah sampel dalam penelitian ini adalah sebanyak 124 orang.

Pada penelitian ini, pengumpulan data dilakukan dengan menggunakan kuesioner (self report) sebagai alat pengumpul data. Kuesioner untuk variabel persepsi masyarakat terhadap kinerja kepolisian menggunakan alat ukur persepsi pada kepolisian yang dikembangkan oleh Prof. Edward R. Maguire dari Department of Justice, Law and Society, American University, Washington, DC, USA. Instrumen ini digunakan dalam penelitian Measuring public perceptions of the police. Instrumen ini berjumlah 27 pertanyaan. Instrumen trust yang digunakan dalam penelitian ini, peneliti kembangkan sendiri berdasarkan dimensi dari trust. Peneliti mengembangkan instrumen trust berdasarkan lima dimensi kunci dari trust menurut Pamela S. Shockley-Zalabak. Instrumen ini berjumlah 37 pertanyaan. 


\section{Hasil Penelitian dan Diskusi}

Setelah dilakukan uji coba validitas dan reliabilitas pada alat ukur persepsi dan trust, peneliti tidak memasukan beberapa aitem yang memiliki nilai koefisien korelasi rendah. Kemudian aitem-aitem lainnya dibentuk menjadi satu set instrumen penelitian yang terdiri dari skala persepsi dan skala trust.

Pelaksanaan penelitian dilakukan di beberapa wilayah DKI Jakarta seperti Slipi Jakarta Barat, Kuningan Jakarta Selatan, Rawamangun Jakarta Timur, serta Manggarai Jakarta Selatan. Teknik pengambilan sampel yang digunakan adalah metode insidental sampling. Peneliti melakukan penyebaran instrumen sebanyak 126 instrumen. Penyebaran instrumen dilakukan pada bulan Desember 2012. Dari 126 instrumen, hanya 124 instrumen yang dapat diolah. Dengan demikian jumlah subjek pada penelitian ini adalah sebanyak 124 orang. Proses penyebaran instrumen ini selain peneliti lakukan sendiri dengan mendatangi beberapa tempat di atas, namun ada juga yang disebar dengan bantuan teman di tempat kerjanya, maupun terhadap orang tua mereka. Peneliti juga menggunakan jejaring sosial berupa facebook untuk menshare instrumen penelitian pada temanteman yang peneliti anggap memenuhi kriteria sebagai subjek dalam penelitian ini.

Data mengenai persepsi masyarakat diperoleh melalui instrumen berupa skala persepsi masyarakat yang terdiri dari 27 aitem dan diisi oleh subjek penelitian. Dari hasil penelitian dan pengolahan data diperoleh skor minimum adalah 27 dan skor maksimum adalah 135. Skor rata-rata (mean) persepsi masyarakat adalah 84,35 dan standar deviasinya adalah 19,030.

Skor persepsi yang diperoleh dari penelitian ini akan dikategorikan menjadi dua yaitu persepsi positif dan persepsi negatif. Penentuan positif dan negatif dilakukan berdasarkan mean kelompok dari data. Dibawah ini disajikan dalam bentuk tabel.

Tabel 1. Kategori Skor Persepsi Masyarakat

\begin{tabular}{ccc}
\hline Kriteria & Jumlah Subjek & \% \\
\hline Positif $(\geq 85)$ & 55 & 55,6 \\
\hline Negatif $(<85)$ & 69 & 44,4 \\
\hline
\end{tabular}

Berdasarkan proses perhitungan pengkategorian skor persepsi masyarakat yang dihitung maka dapat disimpulkan bahwa subjek penelitian yang memiliki skor persepsi lebih besar atau sama dengan 85 dikategorikan memiliki persepsi positif. Sedangkan subjek penelitian yang memiliki skor kurang dari 85 dikategorikan memiliki persepsi negatif.

Berdasarkan tabel di atas dapat diketahui bahwa terdapat 55 subjek dengan presentase $55.6 \%$ yang termasuk dalam kategori memiliki persepsi positif. Terdapat 69 subjek dengan presentase $44.4 \%$ yang termasuk dalam kategori memiliki persepsi negatif. Berikut disajikan dalam bentuk diagram. Sehingga secara umum dapat dilihat bahwa persepsi masyarakat terhadap kepolisian masih cenderung negatif. Hal ini terbukti dari penelitian yang dilakukan menunjukan hasil bahwa lebih banyak subjek yang memiliki persepsi negatif daripada persepsi positif.

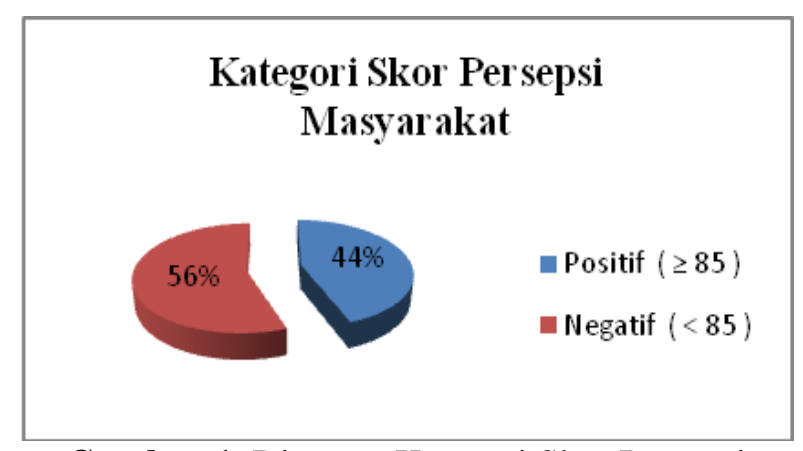

Gambar 1. Diagram Kategori Skor Persepsi 
Data mengenai trust masyarakat diperoleh melalui instrumen berupa skala trust yang terdiri dari 37 item dan diisi oleh 124 subjek penelitian. Dari hasil penelitian dan pengolahan data diperoleh skor minimum adalah 45 dan skor maksimum adalah 160. Skor rata-rata (mean) trust masyarakat adalah 101.15 dan standar deviasinya adalah 18.438 .
Skor trust yang diperoleh dari penelitian ini akan dikategorikan menjadi tiga yaitu tinggi, sedang, dan rendah. Penentuan kategorisasi ini dilakukan berdasarkan mean teoritik dari data.

Berikut ini disajikan dalam bentuk tabel hasil penghitungan kategori skor trust.

Tabel 2. Kategori Skor Trust Masyarakat

\begin{tabular}{ccc}
\hline Kriteria & Frekuensi & \% \\
\hline Tinggi $(>135,66)$ & 4 & 3,2 \\
\hline Sedang $(86,34<\mathrm{x} \leq 135,66)$ & 91 & 73,4 \\
\hline Rendah $(<86,34)$ & 29 & 23,4 \\
\hline
\end{tabular}

Berdasarkan tabel di atas dapat diketahui bahwa terdapat 4 subjek dengan presentase 3.2\% yang termasuk dalam kategori memiliki trust tinggi. Terdapat 91 subjek dengan presentase
$73.4 \%$ yang termasuk dalam kategori memiliki trust sedang. Serta terdapat 29 subjek memiliki trust rendah dengan presentase sebesar $23.4 \%$. Berikut disajikan dalam bentuk diagram:

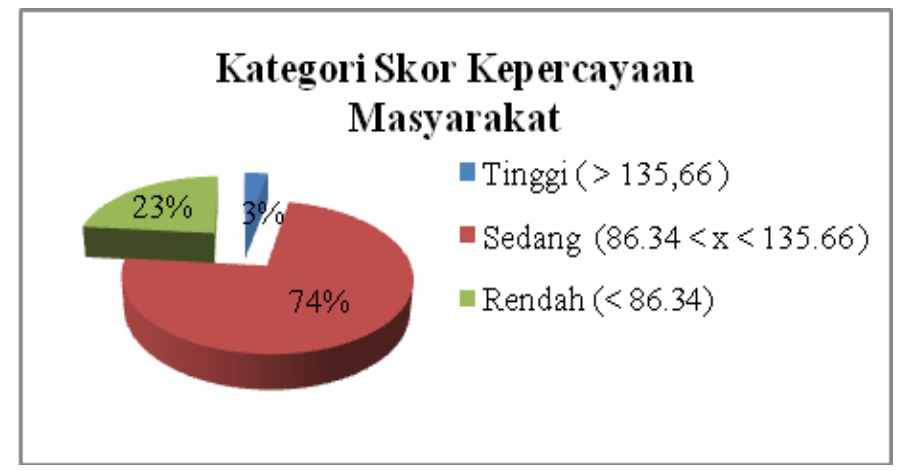

Gambar 2. Diagram Kategori Skor Kepercayaan

Diagram di atas menggambarkan bahwa kecenderungan trust masyarakat pada kepolisian berada pada tingkatan sedang. Masyarakat yang memiliki trust tinggi terhadap kepolisian sangat kecil, bahkan jumlahnya lebih kecil daripada masyarakat yang memiliki trust rendah.

Berdasarkan hasil pengujian dengan analisis regresi sederhana, diperoleh hasil bahwa terdapat pengaruh yang signifikan persepsi masyarakat terhadap trust masyarakat pada kepolisian. Hal ini dapat dilihat dari nilai $\mathrm{F}=74.828 ; \mathrm{p}=0.000<$ 0.05. Hasil pengujian hipotesis dengan menggunakan analisis regresi linear, diperoleh nilai konstanta variabel persepsi masyarakat sebesar 50.765. Hasil koefisien regresi variabel persepsi masyarakat sebesar 0.597. Persamaan regresi berdasarkan data yang ada, yaitu : $\mathrm{Y}=$
$50.765+0.597 \mathrm{X}$. Interpretasi dari persamaan regresi tersebut adalah, jika variabel persepsi masyarakat naik sebesar 50.765, maka variabel trust masyarakat akan naik sebesar 0.597. Hal ini berarti bahwa dalam hubungan antara persepsi dan trust masyarakat pada kepolisian terjadi hubungan dengan arah yang positif.

Berdasarkan hasil perolehan data, dapat disimpulkan bahwa persepsi masyarakat memiliki pengaruh yang signifikan terhadap trust masyarakat. Besar sumbangan persepsi masyarakat terhadap trust masyarakat diketahui dengan melihat perolehan nilai Adjusted $R$ Square. Nilai Adjusted $R$ Square yang diperoleh pada penelitian ini sebesar 0.375 atau sebesar $37.5 \%$. Hal tersebut menunjukkan bahwa ada 
faktor lain sebesar $62.5 \%$ yang mempengaruhi trust masyarakat pada kepolisian.

Hasil penelitian ini sejalan dengan penelitian yang dilakukan oleh Yuning Wu dan Ivan Y. Sun mengenai trust pada kepolisian di China, hasilnya menunjukan bahwa trust masyarakat juga dipengaruhi oleh kepuasan terhadap keselamatan publik, kemampuan pemerintah menangani kejahatan, kualitas hidup dan korupsi dikalangan pejabat pemerintah. Meski persepsi kinerja bukan merupakan satu-satunya faktor yang mempengaruhi trust, namun pengaruh $37.5 \%$ yang disumbangkan cukup memberikan gambaran bahwa kinerja kepolisian merupakan hal penting yang dilihat oleh masyarakat. Hasil ini berarti bahwa kepolisian harus selalu meningkatkan kinerjanya dalam memberikan pelayanan, pengayoman dan menjaga keamanan.

Pengaruh signifikan persepsi terhadap trust yang ditemukan dalam penelitian ini juga sejalan dengan penelitian Liqun Cao, James Frank dan Francis T. Cullen mengenai race, community context and confidence in the police yang menyatakan bahwa persepsi memberikan pengaruh pada trust masyarakat terhadap kepolisian. Penelitiannya menemukan bahwa terdapat pengaruh yang negatif antara persepsi warga mengenai kerusuhan di masyarakat dengan trust terhadap kepolisian. Artinya ketika masyarakat mempersepsikan kerusuhan dalam masyarakat meningkat maka trustnya pada kepolisian menurun. Berbeda dengan hal di atas, dalam penelitian yang sama menemukan bahwa persepsi masyarakat mengenai kemudahan untuk menghubungi kepolisian, memiliki pengaruh positif dengan trust pada kepolisian. Ketika masyarakat mempersepsikan bahwa mudah untuk menghubungi kepolisian maka trust masyarakat pada kepolisian meningkat. Berdasarkan penjelasan di atas terlihat bahwa persepsi pada kinerja kepolisian mempengaruhi trust masyarakat. Ketika kepolisian mampu melaksanakan kinerjanya maka trust masyarakat akan tinggi terhadap kepolisian.

Survey pada masyarakat Los Angeles menunjukkan hasil sebagai berikut persepsi masyarakat mengenai tingkat kejahatan dan gangguan di lingkungan mereka merupakan faktor yang signifikan dalam membentuk opini masyarakat pada kepolisian. Masyarakat yang tidak pernah melakukan kontak dengan kepolisian memiliki persepsi yang lebih positif daripada masyarakat yang pernah kontak dengan kepolisian (Maxson, 2003). Hal ini sejalan dengan hasil penelitian yang telah dilakukan bahwa berurusan dengan kepolisian mempengaruhi persepsi masyarakat. Hal ini juga diperkuat oleh penelitian-penelitian sebelumnya yang menemukan hal serupa seperti penelitian Brown and Coulter, 1983; Dean, 1980; Mastrofski, 1981; Parks, 1984; Scaglion and Condon, 1980 (dalam Cao, 1996).

Penelitian yang dilakukan oleh Jamie L. Flexon, Arthur J. Lurigio, Richard G. Greenleaf mengenai Exploring the dimensions of trust in the police among Chicago juveniles menunjukkan hasil bahwa terdapat hubungan antara trust dengan pengalaman. Hal ini seperti yang diungkapkan oleh Harkrisnowo (2003), bahwa tidak tertutup kemungkinan bahwa trust masyarakat pada kepolisian masih sangat lekat dengan sejarah polisi era prareformasi. Jika dikaitkan dengan penelitian ini maka pengalaman berhubungan dengan kepolisian baik dalam hal pengurusan administrasi ataupun pelanggaran memberikan pengaruh terhadap trust pada kepolisian. Penelitian ini menemukan bahwa lebih banyak subjek yang tidak pernah berhubungan dengan kepolisian memiliki trust yang tinggi terhadap kepolisian dibandingkan dengan subjek yang pernah berhubungan dengan kepolisian.

Berdasarkan pembahasan hasil penelitian ini diketahui bahwa terdapat pengaruh yang signifikan dengan arah yang positif antara persepsi masyarakat pada kinerja kepolisian terhadap trust pada kepolisian. Meski demikian trust juga bisa dipengaruhi oleh hal lain misalnya kepuasan terhadap keselamatan publik, kemampuan pemerintah menangani kejahatan, kualitas hidup dan korupsi dikalangan pejabat pemerintah seperti hasil penelitian Yuning $\mathrm{Wu}$.

\section{Kesimpulan}

Berdasarkan data yang diperoleh dari penelitian ini diketahui bahwa jumlah masyarakat yang memiliki persepsi negatif terhadap kepolisian lebih banyak daripada masyarakat yang memiliki persepsi positif. Kepercayaan masyarakat pada kepolisian berdasarkan penelitian ini berada pada tingkatan kepercayaan 
sedang. Hasil penelitian menunjukan bahwa terdapat pengaruh yang signifikan antara persepsi masyarakat pada kinerja kepolisian terhadap kepercayaan masyarakat pada kepolisian. Pengaruh persepsi masyarakat pada kinerja kepolisian terhadap kepercayaan masyarakat pada kepolisian memiliki hubungan yang positif.

\section{Daftar Pustaka}

Baron, R.A. \& Byrne, Donn. (2005). Psikologi Sosial. Jakarta: Penerbit Erlanga.

Fukuyama, F. (2000). Trust: Kebajikan Sosial dan penciptaan Kemakmuran penerjemah, Ruslani; Yogyakarta: Penerbit Qalam.

Gibson, J.L., J.H. Donnelly Jr, J.M. Ivancevich, R. Konopaske. (2003). Organizational Behaviour: Structure, and Processes ${ }^{\text {th }}$. New York. McGraw-Hill.

Harkrisnowo, H. (2003). Mendorong Kinerja Polri Melalui Pendekatan Sistem Managemen Terpadu. Pidato Dies Natalis Ke-57 PTIK Dalam Rangka Wisuda Sarjana Ilmu Kepolisian Angkatan XXXVIII/Arygya Hwardaya.

Irwanto. (2002). Psikologi Umum. Jakarta: PT Prenhallindo.

Mangkunegara, A.P. (2000). Manajemen Sumber Daya Manusia Perusahaan. Bandung: PT. Remaja Rosdakarya.

Nelson, D.L., Quick, James Campbell. (2005). Understanding Organizational Behavior ${ }^{\text {th2 }}$. USA: Thomson South-Western.

Paine, K.D. (2003). Guidelines for Measuring Trust in Organizations. New Jersey: The Institute for Public Relations.

Prawirosentono, S. (2008). Kebijakan Kinerja Karyawan, Edisi Ketiga, Yogyakarta: BPFE.

Rakhmat, D. (2007). Psikologi Komunikasi. Bandung: PT. Remaja Rosdakarya.
Robbins, S.P. (2003). Perilaku Organisasi Jilid 2. Jakarta: PT. Indeks Kelompok Gramedia.

Santrock, J.W. (2003). Psychology $7^{\text {th }}$. North America. McGraw-Hill.

Shockley-Zalabak,Pamela S., Morreale, Sherwyn P., Hackman Michael Z. (2010). Building the High-Trust Organization. USA: Jossey-Bass and The International Association of Business Communicators.

Sobur, A. (2003). Psikologi Umum. Bandung: Pustaka Setia.

Suparlan, P. (2004). Bunga Rampai Ilmu Kepolisian. Jakarta: Yayasan Pengembangan Kajian Ilmu Kepolisian.

Ancok, D. (2007). Membangun Kepercayaan Menuju Indonesia Madani, Demokratis, dan Damai. Didownload dari http://ancok.staff.ugm.ac.id/ tanggal 27 Januari 2012.

Brown, B., Benedict, W.R., V. Wilkinson, William. (2006). Public Perseptions Of The Police In Mexico: A Case Study. Policing: An International Journal of Police Strategies \& Management 29(1). Emerald.

Hutapea, H. (2008). Pengaruh Saling Ketergantungan, Kepercayaan, dan Keselarasan Tujuan Terhadap Kooperasi dan Kinerja Perusahaan Manufaktur pada Hubungan Kontraktual dengan Pemasoknya. Sumatera Utara: Universitas Asahan. didownload dari http://isjd.pdii.lipi.go.id/index.php/Search. $\mathrm{html}$ ?act $=$ tampil\&id $=5930 \& \mathrm{idc}=28$ tanggal 27 Januari 2012.

Macaskill, A., Brown, Kyle. (2009). Psychological Review of Trust. Sheffield Hallam University.

Maguire, E.R. (2010). Measuring Public Perceptions of the Police. Policing: An International Journal of Police Strategies 
\& Management 33(4) Emerald Group Publishing Limited.

Wu, Y, Y. Sun, Ivan. (2009). Citizen Trust In Police The Case Of China. Police Quarterly 12(2), Sage Publications.
Yamagishi, T. (1998). The Structure of Trust An Evolutionary Game of Mind and Society. Tokyo: Tokyo University Press. 